\title{
A INCOMPATIBILIDADE DA TARIFAÇÃO DA INDENIZAÇÃO POR DANO EXTRAPATRIMONIAL TRABALHISTA À LUZ DOS DIREITOS HUMANOS E DOS DIREITOS FUNDAMENTAIS
}

\author{
The incompatibility of the pricing of the indemnity for extrapatrimonial laboral \\ damage to the light of human rights and fundamental rights
}

\author{
Pastora do Socorro Teixeira LEAL ${ }^{1}$ \\ Igor de Oliveira ZWICKER ${ }^{2}$
}

\begin{abstract}
Resumo: O presente estudo lança um olhar sobre a Reforma Trabalhista, no ponto em que introduziu, na Consolidação das Leis do Trabalho, um sistema tarifário prévio e abstrato de valores indenizáveis dos danos extrapatrimoniais tendo por parâmetro o salário contratual do trabalhador. A partir da análise da diretriz axiológico-normativa constitucional da tutela da pessoa humana, da centralidade dos direitos fundamentais e sociais, do valor social do trabalho, do princípio constitucional da isonomia e diante da "indenizabilidade irrestrita" do dano moral (extrapatrimonial) prevista no art. $5^{\circ}$, incisos V e X, da Constituição da República, ao final se conclui que a tarifação do dano extrapatrimonial na esfera laboral apresenta grave vício material de inconstitucionalidade e contraria diversos tratados internacionais de direitos humanos.
\end{abstract}

Palavras-Chave: Dignidade da pessoa humana. Direitos humanos. Direitos fundamentais e sociais. Tarifação do dano extrapatrimonial.

\footnotetext{
${ }^{1}$ Professora de graduação e de pós-graduação (Mestrado e Doutorado) da Universidade Federal do Pará e da Universidade da Amazônia (PA); Desembargadora do Trabalho do Tribunal Regional do Trabalho da $8^{\mathrm{a}}$ Região (PA/AP); Bacharela e Mestra em Direito pela Universidade Federal do Pará; Doutora em Direito pela Pontifícia Universidade Católica de São Paulo, com Pós-Doutorado pela Universidade Carlos III de Madri (Espanha). ORCID: ID 0000-0001-5265-483X. E-mail: pastoraleal@uol.com.br

${ }^{2}$ Doutorando em Direito pela Universidade Federal do Pará, aprovado em $1^{\circ}$ lugar geral; Mestre em Direitos Fundamentais pela Universidade da Amazônia (PA), aprovado em $1^{\circ}$ lugar geral; Especialista em Economia do Trabalho e Sindicalismo pela Universidade Estadual de Campinas (SP); Especialista em Direito do Trabalho e Processo do Trabalho pela Universidade Cândido Mendes (RJ); Bacharel em Direito e Especialista em Gestão de Serviços Públicos pela Universidade da Amazônia (PA); Analista Judiciário (Área Judiciária) e Assessor Jurídico-Administrativo do Tribunal Regional do Trabalho da $8^{\text {a }}$ Região (PA/AP); Professor de Direito; Autor do livro "Súmulas, orientações jurisprudenciais e precedentes normativos do TST" (São Paulo: LTr, 2015). ORCID: ID 0000-0001-7554-5126. E-mail: igor.zwicker@trt8.jus.br
} 
Abstract: The present study looks at the Labor Reform, in the point where it introduced, in the Consolidation of Labor Laws, a prior and abstract tariff system of compensable amounts of extra-patrimonial damages based on the worker's contractual salary. From the analysis of the axiological-normative constitutional guideline of the protection of the human person, of the centrality of fundamental and social rights, of the social value of work, of the constitutional principle of isonomy and the "unrestricted indemnity" of moral damage (extra-patrimonial) provided for in article 5, items $V$ and $X$, of the Constitution of the Republic, at the end it is concluded that the pricing of extra-patrimonial damage in the labor sphere presents serious material flaw of unconstitutionality and is contrary to several international human rights treaties of which it does the Brazilian State.

Keywords: Dignity of human person. Human Rights. Fundamental and social rights. Extrapatrimonial damages pricing.

Sumário: Introdução; 1. A centralidade dos direitos fundamentais e sociais na Constituição da República; 2. O valor social do trabalho; 3. A tutela da pessoa humana; 4. O princípio constitucional da isonomia; 5. A garantia constitucional fundamental da indenizabilidade irrestrita em contraponto com a tarifação do dano extrapatrimonial na legislação laboral; Conclusão; Referências.

Summary: Introduction; 1. The centrality of fundamental and social rights in the Constitution of the Republic; 2. The social value of work; 3. The protection of the human person; 4. The constitutional principle of isonomy; 5. The fundamental constitutional guarantee of unrestricted indemnity as a counterpoint to the pricing of extra-legal damages in labor legislation; Conclusion; References.

\section{Introdução}

A Lei 13.467/2017, de 13/7/2017, intitulada "Reforma Trabalhista", foi publicada no Diário Oficial da União do dia 14/7/2017 e alterou a Consolidação das Leis do Trabalho, aprovada pelo Decreto-Lei 5.452, de $1^{\circ}$ de maio de 1943, e as Leis 6.019, de 3 de janeiro de 1974, 8.036, de 11 de maio de 1990, e 8.212, de 24 de julho de 1991, "a fim de adequar a legislação às novas relações de trabalho".

Dentre outros pontos, a novel legislação acresceu o Título II-A à Consolidação das Leis do Trabalho, intitulado "Do Dano Extrapatrimonial", composto pelos artigos 223-A a 223-G.

No art. 223-G, a Consolidação das Leis do Trabalho passou a prever um sistema tarifário e prévio, de forma abstrata, às indenizações devidas e decorrentes de danos extrapatrimoniais. 
Segundo o comando em destaque, se o juiz acolher o pedido, deve interpretar a ofensa perpetrada segundo a sua natureza, de leve a gravíssima, e fixará a indenização a partir desses parâmetros, "vedada a acumulação", e chegando ao valor máximo de até cinquenta vezes o último salário contratual do trabalhador, quer na condição de ofendido, quer na condição de ofensor, para as ofensas de natureza gravíssima, sendo esse o critério previamente estabelecido para todas elas - o salário contratual do obreiro.

Posteriormente, o Presidente da República adotou, com força de lei, a Medida Provisória 808/2017, de 14/11/2017, publicada no Diário Oficial da União do mesmo dia (edição extra), que passou a prever que tais parâmetros não aplicar-se-iam na ocorrência do evento morte (art. 223-G, § 5 , da Consolidação das Leis do Trabalho).

Porém, a Medida Provisória 808/2017 perdeu sua eficácia, desde a edição, porque não foi convertida em lei no prazo de que tratam os $\S \S 3^{\circ}$ e $7^{\circ}$ do art. 62 da Constituição da República; e ainda não sobreveio, sequer, o decreto legislativo para disciplinar as relações jurídicas ocorridas durante sua respectiva vigência, o que pode resultar na submissão das relações jurídicas constituídas e decorrentes de atos praticados durante a vigência da Medida Provisória à disciplina normativa por ela estabelecida (art. 62, §§ $3^{\circ}$ e 11 , da Constituição da República).

Desse modo, se aplicada a literalidade do art. 223-G da Consolidação das Leis do Trabalho, e considerando o atual valor do salário mínimo, desde $1^{\circ}$ de janeiro de 2018 fixado na quantia de $\mathrm{R} \$ 954,00$ (novecentos e cinquenta e quatro reais), segundo Lei 13.152/2015 e Decreto 9.255/2017, caso morra o trabalhador - evento presumivelmente de natureza gravíssima -, a indenização pelo dano perpetrado será de até $\mathrm{R} \$ 47.700,00$ (quarenta e sete mil e setecentos reais), ou seja, coloca o valor da vida humana no patamar aproximado do preço de um carro popular.

Ainda, veja-se exemplo de um engenheiro de obras e um pedreiro que morrem em um acidente do trabalho, em idêntica circunstância e no mesmo evento fatal, percebendo o primeiro o salário contratual de $\mathrm{R} \$ 10.000,00$ (dez mil reais) e o segundo, o salário mínimo.

Nesse exemplo, a indenização referente à morte do engenheiro de obras será de até $\mathrm{R} \$ 500.000,00$ (quinhentos mil reais) e a do pedreiro, até $\mathrm{R} \$ 47.700,00$ (quarenta e sete mil e setecentos reais). 
O que justifica essa tarifação, prévia e abstrata pela legislação infraconstitucional, limitadora da "indenizabilidade irrestrita" prevista no art. 5\%, incisos V e X, da Constituição da República?

O que justifica essa tarifação, prévia e abstrata pela legislação infraconstitucional, à revelia do critério de proporcionalidade previsto no art. $5^{\circ}$, inciso $\mathrm{V}$, da Constituição da República?

O que justifica essa diferença entre trabalhadores?

O que justifica essa diferença entre o Direito do Trabalho e o direito comum, esse último em patamar nitidamente superior de cidadania e dignidade, em que pese a primazia do trabalho e a natureza jurídica das relações laborais?

Buscaremos analisar tais inquietações a partir da exigência de coerência do sistema jurídico como exigência de justiça, o que impõe seja levado em conta o atendimento aos fins sociais e às exigências do bem comum, com fundamento no resguardo e na promoção da dignidade da pessoa humana, matriz axiológico-normativa do ordenamento jusconstitucional brasileiro e dos tratados internacionais de direitos humanos.

\section{A centralidade dos direitos fundamentais e sociais na Constituição da República}

A Constituição da República Federativa do Brasil de 1988, batizada de "Carta Cidadã”, foi revolucionária. ${ }^{3}$ Diferentemente da Carta de Lei de 1824 - que mandou observar a Constituição Política do Império, oferecida e jurada por Sua Majestade o Imperador -, das Constituições da República dos Estados Unidos do Brasil, de 1891, 1934, 1937 e 1946, e da Constituição da República Federativa do Brasil, de 1967 (seja em seu texto originário, seja com as modificações trazidas pela Emenda Constitucional 1/1969), a Constituição promulgada em 5 de outubro de 1988 fez uma opção e quis mostrar, desde o início do seu texto, ideais e valores supremos que devem bem delinear e formatar a concepção jurídica de Estado Democrático de Direito, visto "não como uma aposição de conceitos, mas sob um

\footnotetext{
${ }^{3}$ Revolucionária, mas tardia, como nos parece ser a tradição brasileira. Basta lembrar que Georg Jellinek (18511911), ao comentar a Declaração dos Direitos do Homem e do Cidadão (França, 1789), em compasso com outros atos constitucionais da época, disse o seguinte: "Em todas essas Constituições, a declaração de direitos ocupa o primeiro lugar. Somente em segundo lugar vem juntar-se o plano ou o quadro de governo." (JELLINEK, 2015, p. 95, destaque nosso).
} 
conteúdo próprio onde estão presentes as conquistas democráticas, as garantias jurídico-legais e a preocupação social". 4

Nesse diapasão, o texto constitucional de 1988, já em seu Título I, traz aqueles que serão seus princípios fundamentais. A centralidade nos direitos fundamentais se mostra evidente, em nosso sentir, seja na topografia inovadora de Constituição de 1988, que diferentemente das Constituições anteriores - já inicia elencando os princípios e objetivos fundamentais e, ato contínuo, consagra direitos e garantias fundamentais, seja pelo próprio conteúdo material desses artigos, cuja leitura perpassa, em especial, os arts. $1^{\circ}$, II, III e IV, $3^{\circ}$, I, III e IV, e $4^{\circ}$, II e IX, da Constituição da República, isto é, a partir da premissa de que o Estado Democrático de Direito somente se sustenta em uma base cidadã e democrática, fundada na cidadania, na dignidade da pessoa humana, nos valores sociais do trabalho e nos valores sociais da livre iniciativa, ${ }^{5}$ que objetiva, fundamentalmente, a construção de uma sociedade livre, justa e solidária, com erradicação da pobreza e da marginalização, a redução das desigualdades sociais e regionais e a promoção do bem de todos; que reconhece, em nível global, a prevalência dos direitos humanos e o dever de cooperação entre os povos para o progresso da humanidade.

Os direitos sociais têm relevo, em sua essência, nos artigos $6^{\circ}$ e seguintes da Constituição da República - com o registro de que, por fazerem parte do Capítulo II do Título I, são considerados, tal qual os direitos e deveres individuais e coletivos (Capítulo I), previstos no art. $5^{\circ}$, direitos e garantias fundamentais, de aplicação imediata, na forma do art. $5^{\circ}, \S 1^{\circ}$, que faz referência ao texto expresso no Título I, e não no Capítulo I, que inaugura o art. $5^{\circ}$, "de tal sorte que todas as categorias de direitos fundamentais estão sujeitas, em princípio, ao mesmo regime jurídico"6.

Sobre a qualidade desses direitos - eminentemente humanos, inerentes à tutela da dignidade da pessoa humana -, observa Wagner Balera ${ }^{7}$ que "o constituinte coloca, pois, a proteção social como um dos direitos humanos cuja garantia é a própria Lei Maior”.

\footnotetext{
4 STRECK, Lenio Luiz; MORAIS, Jose Luis Bolzan de. In: CANOTILHO, José Joaquim Gomes et al. Comentários à Constituição do Brasil. Saraiva/Almedina: São Paulo/Portugal, 2013, p. 113.

${ }^{5}$ Repetimos "valores sociais" para ressaltar o que muitas vezes se esquece: quando a Constituição da República eleva a fundamento da República Federativa do Brasil "os valores sociais do trabalho e da livre iniciativa”" (art. $1^{\circ}$, inciso IV), não diz valores sociais do trabalho "e a livre iniciativa" e sim "e da livre iniciativa"; em outras palavras, quando a Constituição da República fala em "valores sociais", assim o faz, no mesmo inciso, tanto para o trabalho quanto para a livre iniciativa.

${ }^{6}$ SARLET, Ingo Wolfgang. In: CANOTILHO, José Joaquim Gomes et al. Comentários à Constituição do Brasil. Saraiva/Almedina: São Paulo/Portugal, 2013, p. 514-515.

${ }^{7}$ BALERA, Wagner. A seguridade social na Constituição de 1988. São Paulo: RT, 1989, p. 17.
} 
Ainda quanto à sua proteção, os direitos sociais têm em seu favor o princípio da vedação ao retrocesso social, bem explicitado na cabeça do art. $7^{\circ}$ da Constituição da República, "a coibir medidas de cunho retrocessivo" que "venham a desconstituir ou afetar gravemente o grau de concretização já atribuído a determinado direito fundamental (e social), o que equivaleria a uma violação à própria Constituição Federal"».

Porém, a simples vedação ao retrocesso social não satisfaz a Carta Cidadã, considerada a necessidade premente da vida, de se caminhar para frente, de evoluir, de agir, de tornar efetiva a promessa constitucional de uma sociedade livre, justa e solidária. Nesse sentido, a Constituição consagra autêntica "cláusula de avanço social", 9 quando elenca, no art. $7^{\circ}$, direitos mínimos dos trabalhadores urbanos e rurais, "além de outros que visem à melhoria de sua condição social”.

Segundo o Supremo Tribunal Federal, "o princípio da proibição do retrocesso impede, em tema de direitos fundamentais de caráter social, que sejam desconstituídas as conquistas já alcançadas pelo cidadão ou pela formação social em que ele vive". ${ }^{10}$

Essa também é a ideologia consagrada no Pacto Internacional sobre Direitos Econômicos, Sociais e Culturais (Decreto 591/1992, que ostenta posição hierárquiconormativa de supralegalidade ${ }^{11}$ no ordenamento jurídico brasileiro, consoante iterativa, atual e notória jurisprudência do Supremo Tribunal Federal), e seu Protocolo Adicional (Protocolo de São Salvador), que trazem a ideia de permanente estado de progressividade dos direitos.

\footnotetext{
${ }^{8}$ SARLET, Ingo Wolfgang. In: CANOTILHO, José Joaquim Gomes et al. Comentários à Constituição do Brasil. Saraiva/Almedina: São Paulo/Portugal, 2013, p. 542-543.

${ }^{9}$ ZWICKER, Igor de Oliveira. Súmulas, orientações jurisprudenciais e precedentes normativos do TST. São Paulo: LTr, 2015, p. 152.

${ }_{10}$ Supremo Tribunal Federal, Agravo Regimental no Recurso Extraordinário com Agravo n. 639.337/SP, Segunda Turma, Relator Ministro Celso de Mello, julgado em 23/8/2011, DJe publicado em 15/9/2011; no mesmo sentido, Supremo Tribunal Federal, Agravo Regimental no Recurso Extraordinário n. 581.352/AM, Segunda Turma, Relator Ministro Celso de Mello, julgado em 29/10/2013, DJe publicado em 22/11/2013.

11 "No julgamento dos recursos extraordinários ns. 349.703/RS e 466.343/SP e dos habeas corpus ns. 87.585/TO e 92.566/SP (Informativo n. 531 do STF), a Suprema Corte pacificou a questão, definindo expressamente a posição hierárquico-normativa dos tratados internacionais: (i) se sobre direitos humanos, aprovados pelo quórum qualificado do art. $5^{\circ}, \S 3^{\circ}$, da Constituição, são equivalentes a emendas constitucionais e têm natureza e hierarquia constitucional; (ii) se sobre direitos humanos, mas sem a aprovação pelo citado quórum qualificado, inclusive os já ratificados em momento anterior ao advento da Emenda Constitucional n. 45/2004, têm natureza e hierarquia supralegal; (iii) se não tratarem sobre direitos humanos (os ajustes internacionais da OMC em geral, por exemplo), têm natureza legal; (iv) nenhum tratado internacional tem natureza supraconstitucional." ZWICKER, Igor de Oliveira. A dupla incompatibilidade vertical material do artigo 477-A da Consolidação das Leis do Trabalho. Jornal do $58^{\circ}$ Congresso Brasileiro de Direito do Trabalho. São Paulo, LTr, v. 58, p. 61-63, jun. 2018, p. 61-62, destaques nossos)
} 
Nesse sentido, Aline Paula Bonna ${ }^{12}$ diz que, com o Pacto, "o Brasil se comprometeu a implementar, progressivamente e com o máximo de seus recursos disponíveis, os direitos ligados à igualdade". Ainda com relação à noção de progressividade, "extrai-se a vedação do retrocesso, como um vetor dinâmico e unidirecional positivo, que impede a redução do patamar de tutela já conferido à pessoa humana". ${ }^{13}$

Tal cláusula - de avanço social, corolário da vedação ao retrocesso social - simboliza, inclusive, um dos quatro status pensados pelo jurista alemão Georg Jellinek (1851-1911), teoria que se justifica não somente "por sua importância histórica como exemplo de uma grande construção jurídica, conceitual e teórica", mas por sua "relevância como fundamento de classificações dos direitos fundamentais" e como "paradigma de uma teoria de posições globais abstratas". ${ }^{14}$

Para Jellinek, os direitos fundamentais trazem quatro status: (i) passivo (status subiectiones); (ii) negativo (status libertatis); (iii) positivo (status civitatis); e (iv) ativo (status da cidadania ativa). ${ }^{15} \mathrm{O}$ status positivo bem simboliza a promessa constitucional de agir - mutatis mutandis, o não agir representa uma omissão -, no sentido de conferir ao Estado o poder/dever de "prestações positivas", em conferir ao indivíduo o status cívico "quando the garante pretensões à sua atividade" e "cria meios jurídicos para a realização desse fim". ${ }^{16}$

Nesse diapasão, é importante atestar que, quando o Pacto Internacional sobre Direitos Econômicos, Sociais e Culturais - de posição hierárquico-normativa de supralegalidade, reitere-se - fala em "progressividade", afirma, taxativamente, que cada Estado deve se comprometer a adotar medidas, tanto por esforço próprio como pela assistência e cooperação internacionais, principalmente nos planos econômico e técnico, "até o máximo de seus recursos disponíveis", que visem a assegurar por todos os meios apropriados o pleno exercício dos direitos, "incluindo, em particular, a adoção de medidas legislativas".

Assim, o status positivo de que falávamos, que simboliza a promessa constitucional do agir, deve ser voltado também à exigência direcionada ao Estado de não apenas manter a sua

\footnotetext{
${ }^{12}$ BONNA, Aline Paula. A vedação do retrocesso social como limite à flexibilização das normas trabalhistas brasileiras. Revista do Tribunal Regional do Trabalho da $3^{a}$ Região, Belo Horizonte, v. 47, n. 77, p. 51-66, jan./jun. 2008, p. 60.

${ }^{13}$ BONNA, Aline Paula. A vedação do retrocesso social como limite à flexibilização das normas trabalhistas brasileiras. Revista do Tribunal Regional do Trabalho da $3^{a}$ Região, Belo Horizonte, v. 47, n. 77, p. 51-66, jan./jun. 2008, p. 60.

${ }^{14}$ ALEXY, Robert. Teoria dos direitos fundamentais. São Paulo: Malheiros, 2008, p. 254.

${ }^{15}$ ALEXY, Robert. Teoria dos direitos fundamentais. São Paulo: Malheiros, 2008, p. 255.

${ }^{16}$ ALEXY, Robert. Teoria dos direitos fundamentais. São Paulo: Malheiros, 2008, p. 263-264.
} 
legislação hígida e protegida do retrocesso social como, ainda, criar legislação que possa promover o avanço social, de forma progressiva, permanentemente.

\section{O valor social do trabalho}

A importância do elemento trabalho - e sua necessidade de valorização, proteção e salvaguarda - é premissa aparentemente unânime em todo o mundo, ousamos dizer. Basta voltar os olhos à Declaração Universal dos Direitos Humanos, por exemplo - maior documento histórico celebrado após o fim da Segunda Grande Guerra Mundial -, para entender que "todo ser humano tem direito ao trabalho, à livre escolha de emprego, a condições justas e favoráveis de trabalho e à proteção contra o desemprego" (art. XXIII, item $1)$.

A Declaração da Filadélfia, anexo à Constituição da Organização Internacional do Trabalho, reafirma princípios de natureza fundamental sobre os quais repousa esta Organização, cujos princípios basilares são os de que trabalho não é uma mercadoria, a penúria, seja onde for, constitui um perigo para a prosperidade geral e a luta contra a carência, em qualquer nação, deve ser conduzida com infatigável energia, e por um esforço internacional contínuo e conjugado, no qual os representantes dos empregadores e dos empregados discutam, em igualdade, com os dos Governos, e tomem com eles decisões de caráter democrático, visando ao bem comum.

Dentro do seio constitucional, a situação não é diferente.

A Constituição da República de 1988, já em seu Título I, traz aqueles que serão seus princípios fundamentais. Deste conteúdo jurídico, relembre-se, colhemos premissas norteadoras de toda a premissa constitucional pensada pelo Estado Democrático de Direito: a cidadania (art. $1^{\circ}$, II), a dignidade da pessoa humana (art. $1^{\circ}$, III), os valores sociais do trabalho e os valores sociais da livre iniciativa (art. $1^{\circ}$, IV), a construção de uma sociedade livre, justa e solidária (art. $\left.3^{\circ}, \mathrm{I}\right)$, a erradicação da pobreza e da marginalização e a redução das desigualdades sociais e regionais (art. $3^{\circ}, \mathrm{III}$ ), a promoção do bem de todos (art. $3^{\circ}, \mathrm{IV}$ ) e o reconhecimento, em nível global, da prevalência dos direitos humanos (art. $4^{\circ}$, II) e do dever de cooperação entre os povos para o progresso da humanidade (art. $4^{\circ}$, IX).

A par disso, entre inúmeros outros comandos constitucionais, é cediço que a ordem econômica fundada na valorização do trabalho humano e na livre iniciativa, tem por fim assegurar a todos existência digna, conforme ditames de justiça social, e tem por princípios, 
entre outros, a função social da propriedade - nela incluída o conceito de empresa e da pessoa jurídica do empregador -, a defesa do meio ambiente - nele compreendido o do trabalho -, a redução das desigualdades regionais e sociais e a busca do pleno emprego (arts. 170, caput e III, VI, VII e VIII, e 200, VIII).

Ainda, a ordem social tem como base o primado do trabalho, e como objetivo o bemestar social e a justiça social (art. 193). Por fim, todos têm direito ao meio ambiente ecologicamente equilibrado, nele compreendido o do trabalho, essencial à sadia qualidade de vida, impondo-se ao Poder Público e à coletividade o dever de defendê-lo e preservá-lo para as presentes e futuras gerações (arts 200, VIII, e 225).

\section{A tutela da pessoa humana}

A racionalização do Direito pode ser compreendida por meio do conceito de Max Weber, que subdivide a racionalidade formal, fechada e imune a influências externas, a partir de uma "neutralidade axiológica", da racionalidade material, desenvolvida dentro de um campo influenciável por motivações e disposições outrem - "escolhas axiológicas" -, como a ética, a religiosidade, a sociologia, a psicologia e as políticas econômicas. ${ }^{17}$

A ideia de um ordenamento axiológico e teleológico se dá por meio da tessitura da racionalidade material, que se utiliza justamente daquelas técnicas de enunciação genérica e da hermenêutica adequada, que permite ao juiz, ao julgar o caso concreto, implementar uma decisão que não atenda apenas a uma lógica formal-abstrata de justiça, mas de efetivamente visualizar o que é a justiça naquele caso concreto, influenciável por motivações externas como a probidade, a boa-fé, a ética e a justiça concreta (avaliação concreta e não a mera reprodução de normas abstratas).

Esses "fatores influenciáveis" são de ordem intrajurídica (ou de ordem lógica) e extrajurídicas, que são as "motivações outrem" (fatores de ordem externa, como a Psicologia, a Sociologia, a Medicina, a ética, a probidade, a boa-fé etc.).

Isso se percebe, claramente, dentro do conteúdo da própria Constituição da República - de modo que o aplicador do Direito que se arvora em critérios puramente formais-racionais não aplica adequadamente a Lei Maior, em nosso sentir -, como se vê, por exemplo, nas seguintes partes destacadas:

\footnotetext{
${ }^{17}$ WEISS, Raquel. Max Weber e o problema dos valores: as justificativas para a neutralidade axiológica. Revista de Sociologia e Política, Curitiba, v. 22, n. 49, p. 113-137, mar. 2014.
} 
- $\quad$ Cidadania (art. $1^{\circ}$, II);

- $\quad$ Dignidade da pessoa humana (art. $1^{\circ}$, III);

- Valores sociais do trabalho (art. $\left.1^{\circ}, \mathrm{IV}\right)$;

- Valores sociais da livre iniciativa (art. $\left.1^{\circ}, \mathrm{IV}\right)$;

- $\quad$ Sociedade livre, justa e solidária (art. $\left.3^{\circ}, \mathrm{I}\right)$;

- $\quad$ Bem de todos (art. $\left.3^{\circ}, \mathrm{IV}\right)$

- $\quad$ Função social da propriedade (arts. $5^{\circ}$, XXIII, e 170, III);

- Valorização do trabalho humano (art. 170, caput);

- Existência digna (art. 170, caput);

- $\quad$ Igualdade material (arts. $3^{\circ}$, III, $5^{\circ}$, caput, e 170, VII);

- Defesa do consumidor (art. 170, V);

- $\quad$ Pleno emprego (art. 170, VIII);

- $\quad$ Primado do trabalho (art. 193);

- $\quad$ Bem-estar social (art. 193);

- Justiça social (art. 170, caput, e 193).

Essa rematerialização, com a mudança do paradigma para um modelo socialhumanista, se obtém tanto com a utilização de standards, cláusulas gerais e conceitos jurídicos indeterminados como mecanismos de intervenção na economia e conformação e configuração das relações sociais como pelo atendimento, pelas decisões judiciais, de valores não meramente econômicos, mas éticos e de justiça social-material.

Os direitos fundamentais e sociais são atributos viscerais da condição humana, como bem acentua Tepedino,${ }^{18}$ razão pela qual demandam técnica de proteção adequada.

Proteger adequadamente pressupõe concretizar os comandos normativos, torná-los efetivos. A concretização é o "ato de concretizar(-se)", de tornar(-se) concreto, real, efetivar(se), realizar(-se), materializar(-se)". ${ }^{19}$ Segundo Maria Helena Diniz ${ }^{20}$ na lógica jurídica, coerência é a "ausência de contradição entre partes de um argumento". Essa contradição somente pode ser extirpada por ditames de "igualdade e, portanto, de justiça". ${ }^{21}$

18 TEPEDINO, Gustavo. Cidadania e direitos da personalidade. Cadernos da Escola de Direito e Relações Internacionais das Faculdades do Brasil, Paraná, v. 1, n. 3, p. 15-31, jan./jun. 2003.

${ }^{19}$ HOUAISS, Antônio; VILLAR, Mauro de Salles; FRANCO, Francisco Manoel de Mello. Dicionário Houaiss da língua portuguesa. Rio de Janeiro: Objetiva, 2009, p. 514.

${ }^{20}$ DINIZ, Maria Helena. Dicionário jurídico. 2. ed. rev., atual. e aum. São Paulo: Saraiva, 2005. Vol. 1, A-C, p. 761.

${ }^{21}$ LEAL, Pastora do Socorro Teixeira. "Dialogo das fontes" e coerência na concretização de direitos fundamentais. In: VELOSO, Zeno; OLIVEIRA, Frederico Antônio Lima de; BACELAR, Jeferson Antônio 
O sistema jurídico, para ser justo, requer coerência na interpretação e aplicação das normas. ${ }^{22} \mathrm{O}$ ordenamento deve ser pensado a partir de um regramento de justiça, de natureza valorativa, de modo que o sistema a ele (ao ordenamento) correspondente só pode ser uma ordenação axiológica e teleológica - na qual o sentido teleológico não é utilizado no sentido estrito de pura conexão de meios aos fins, mas no sentido mais lato de realização de escopos e de valores. ${ }^{23}$

Os direitos fundamentais e sociais são normas de caráter aberto, tendo em vista que seria impossível a fixação de um rol taxativo, estático, que previamente abarcasse todas as situações que envolvessem a fundamentalidade dos direitos. ${ }^{24}$ Dentro desse amplo aspecto de fundamentalidade, reside a dignidade da pessoa humana.

Segundo Cristiano Chaves de Farias, Nelson Rosenvald e Felipe Peixoto Braga Netto, ${ }^{25}$ a dignidade "diz com a condição humana do ser humano" e "guarda relação com as imprevisíveis e ilimitadas manifestações da personalidade humana”. Quanto aos mecanismos de indenidade da pessoa humana, os autores sugerem, em breves linhas, os seguintes aspectos:

\begin{abstract}
(a) amplíssima tutela às situações existenciais da pessoa humana, seja pela ameaça a um ilícito (tutela inibitória da personalidade), como após a concretização do dano (reparação pelo dano moral); (b) extensão desta tutela aos nascituros - como seres humanos dotados de direitos da personalidade desde a concepção intrauterina -, e também aos incapazes, afinal capacidade e personalidade são conceitos que não se confundem; (c) recusa da tese quanto à possibilidade de a pessoa jurídica titularizar situações existenciais e, portanto, ter acesso à reparação pelo dano moral; (d) recusa de qualquer concepção que suprima a reparação pelo dano moral em razão do comportamento pretérito do ofendido. ${ }^{26}$
\end{abstract}

A tutela da dignidade da pessoa humana corresponde, portanto, à concretização de direitos fundamentais e sociais, pétreos e de aplicação imediata (arts. $5^{\circ}, \S 1^{\circ}$, e $60, \S 4^{\circ}, \mathrm{IV}$, da Constituição da República), o que demanda uma hermenêutica adequada, que possa resguardar e promover a dignidade da pessoa humana e sua elevada carga axiológica.

Fernandes (orgs.). Ciência e interpretação do Direito: homenagem a Daniel Coelho de Souza. Rio de Janeiro: Lumen Juris, 2016, p. 1.

22 LEAL, Pastora do Socorro Teixeira. "Dialogo das fontes" e coerência na concretização de direitos fundamentais. In: VELOSO, Zeno; OLIVEIRA, Frederico Antônio Lima de; BACELAR, Jeferson Antônio Fernandes (orgs.). Ciência e interpretação do Direito: homenagem a Daniel Coelho de Souza. Rio de Janeiro: Lumen Juris, 2016, p. 1.

${ }^{23}$ CANARIS, Claus-Wilhelm. Pensamento sistemático e conceito de sistema na ciência do direito. Lisboa: Fundação Calouste Gulbenkian, 2008, p. 66-67.

${ }^{24}$ LEAL, Pastora do Socorro Teixeira. "Dialogo das fontes" e coerência na concretização de direitos fundamentais. In: VELOSO, Zeno; OLIVEIRA, Frederico Antônio Lima de; BACELAR, Jeferson Antônio Fernandes (orgs.). Ciência e interpretação do Direito: homenagem a Daniel Coelho de Souza. Rio de Janeiro: Lumen Juris, 2016, p. 2.

${ }^{25}$ FARIAS, Cristiano Chaves de; ROSENVALD, Nelson; BRAGA NETTO, Felipe Peixoto. Curso de Direito Civil: responsabilidade civil. 2. ed. rev., atual. e ampl. São Paulo: Atlas, 2015. vol. 3, p. 14.

${ }^{26}$ FARIAS, Cristiano Chaves de; ROSENVALD, Nelson; BRAGA NETTO, Felipe Peixoto. Curso de Direito Civil: responsabilidade civil. 2. ed. rev., atual. e ampl. São Paulo: Atlas, 2015. vol. 3, p. 14. 


\section{O princípio constitucional da isonomia}

A Constituição da República, após relatar quais são seus princípios (art. $1^{\circ}$ ) e objetivos fundamentais (art. $3^{\circ}$ ), inclusive no âmbito internacional (art. $4^{\circ}$ ), inaugura, logo em seguida, o seu Título II, que consagra e consolida direitos e garantias fundamentais expressos (mormente os arts. $5^{\circ}$ a 12 ), no qual eleva a patamar máximo, logo no primeiro artigo do Título (art. $5^{\circ}$ ), a premissa que se expandirá para todo o ordenamento jusconstitucional brasileiro: a de que todos somos iguais perante a lei, sem distinção de qualquer natureza.

A igualdade se apresenta, na Constituição da República, "não apenas como regra constitucional, mas também como autêntico princípio constitucional, sendo, portanto, uma norma constitucional". ${ }^{27}$

Segundo a autora, a igualdade na lei representa um sentido potencialmente proativo, "que se conjuga com liberdade positiva e implica vedações de tratamentos desiguais a pessoas em situações de igualdade, repelindo-se leis discriminatórias e arbitrárias que antes garantiam privilégios a alguns". ${ }^{28}$

Segundo premissa angular de Boaventura de Sousa Santos e João Arriscado Nunes, ${ }^{29}$ temos o direito a ser iguais quando a nossa diferença nos inferioriza e o direito a ser diferentes quando a nossa igualdade nos descaracteriza, daí a necessidade de uma igualdade que reconheça as diferenças e de uma diferença que não produza, alimente ou que reproduza as desigualdades.

Nesse sentido, Bandeira de Mello estabelece alguns parâmetros visando entender o caráter lícito ou não de determinados tratamentos legais diferenciados. Para o autor, não são admitidas discriminações juridicamente intoleráveis (à conclusão similar parece ter chegado Perelman quando afirma que os tratamentos desiguais de lei a pessoas ou grupos sociais não são admissíveis quando forem socialmente inaceitáveis); deve existir um vínculo entre a peculiaridade diferencial da pessoa ou grupo e a desigualdade de tratamento à pessoa ou ao grupo conferida, e esta correlação tem de ser compatível com os interesses prestigiados pela Constituição. Não se admite tratamento diferenciado motivado por distinções odiosas, por preconceito, tomadas gratuitamente. Além disso, este fator diferencial deve existir na pessoa, grupo, coisa ou situação a ser tratada de forma diferente e jamais fora delas; não se admite que pessoas sejam de antemão individualizadas pela lei, exigese que a lei que estabeleça um tratamento diferenciado seja abstrata, que toda "açãotipo" nela prevista faça incidir a regra. Assim, quando a norma for reproduzida

\footnotetext{
${ }^{27}$ LORENTZ, Lutiana Nacur. A norma da igualdade e o trabalho das pessoas portadoras de deficiência. 2. ed. São Paulo: LTr, 2016, p. 19.

${ }^{28}$ LORENTZ, Lutiana Nacur. A norma da igualdade e o trabalho das pessoas portadoras de deficiência. 2. ed. São Paulo: LTr, 2016, p. 26.

29 SANTOS, Boaventura de Sousa; NUNES, João Arriscado. Introdução: para ampliar o cânone do reconhecimento, da diferença e da igualdade. In: SANTOS, Boaventura de Sousa (org.). Reconhecer para libertar: os caminhos do cosmopolitismo multicultural. Rio de Janeiro: Civilização Brasileira, 2003, p. 25-68, p. 56.
} 
qualquer um pode se colocar abaixo da mesma situação-tipo e provocar sua incidência, desde que haja previsão constitucional nesse sentido. ${ }^{30}$ (destaques nossos)

A partir de tais premissas, é possível, ainda no campo da isonomia, reconhecer que, dentro das relações laborais - justamente em razão dessa norma -, há flagrante desigualdade no âmbito material, o que demanda igualização pela própria legislação.

Com efeito, o direito - material e processual - do trabalho se desenvolve em torno de verbas e haveres, em sua maioria esmagadora, de natureza alimentar e superprivilegiada, que encontram seu ápice no elemento salário, que é um dos pressupostos objetivos para a configuração da relação de emprego (o pressuposto da onerosidade).

De natureza alimentar, pois assim erigiu a Lei Maior, benefícios previdenciários e indenizações por morte ou por invalidez a esse patamar, na forma do art. 100, $\S 1^{\circ}$, da Constituição da República. Mutatis mutandis, a regra tem precedência nos arts. 182 da Constituição de 1934, 95 da Constituição de 1937 e 204 da Constituição de 1946 e arts. 112 e 117 da Constituição de 1967, esse último com a redação dada pela Emenda Constitucional $1 / 1969$.

De natureza superprivilegiada, porque assim estabeleceu o Código Tributário Nacional, na cabeça do art. 186, com redação dada pela Lei Complementar 118/2005, quando disse que o crédito tributário prefere a qualquer outro, seja qual for sua natureza ou o tempo de sua constituição, "ressalvados os créditos decorrentes da legislação do trabalho ou do acidente de trabalho".

Por tais razões, aliás, é que o Direito do Trabalho tem caráter protetivo, diante da manifesta vulnerabilidade do empregado, uma vez que no contrato de trabalho as prestações devidas alcançam a tutela da pessoa humana do trabalhador em face do poder diretivo do empregador.

De outra banda, mesmo em se considerando o aspecto estritamente patrimonial, a vulnerabilidade nele também se faz manifesta. Nesse aspecto, Teresa Negreiros ${ }^{31}$ batiza de paradigma da essencialidade a necessidade de proteção daquele que se utiliza do bem objeto do contrato - para a sua sobrevivência.

No contrato de trabalho, uma das partes - o trabalhador - encontra-se em manifesto estado de vulnerabilidade tanto na esfera do ser quanto na esfera do ter. A higidez e a

\footnotetext{
${ }^{30}$ LORENTZ, Lutiana Nacur. A norma da igualdade e o trabalho das pessoas portadoras de deficiência. 2. ed. São Paulo: LTr, 2016, p. 28.

${ }^{31}$ NEGREIROS, Teresa. Teoria do contrato: novos paradigmas. 2. ed. Rio de Janeiro: Renovar, 2006, p. 459463.
} 
segurança de seus bens e interesses existenciais, direitos fundamentais, direitos da personalidade, que devem ser amplamente tutelados para que o trabalho seja digno, encontram-se submetidos à gestão do empregador e tem no objeto patrimonial do contrato - o salário, que recebe em troca da sua força de trabalho - sua única possibilidade de existência digna, o que legitima a intervenção estatal na autonomia da vontade privada, dada a assimetria característica da relação contratual.

A par de tudo que foi exposto, reprise-se que o trabalho - e o direito ao trabalho digno - é um direito social fundamental, consagrado no art. $6^{\circ}$ da Constituição da República, cujo objeto final, para o trabalhador, não se restringe ao salário que recebe pela força de trabalho que coloca à disposição do empregador, mas pressupõe a tutela de sua pessoa no ambiente laboral.

Outros direitos sociais fundamentais expressos no art. $6^{\circ}$, em sua maioria, dependem, primariamente, do trabalho humano e do fruto do labor, que é o salário: em que pese o dever de prestação positiva estatal (o status civitatis, um dos quatro status pensados por Georg Jellinek, como já abordamos), sabe-se que a educação, a saúde, a alimentação, a moradia, o transporte, o lazer e a previdência social estão contidos no conteúdo jurídico-constitucional do salário, que deve ser capaz de atender às necessidades vitais básicas do indivíduo e da sua família com o dispêndio desses direitos sociais fundamentais (art. $7^{\circ}, \mathrm{IV}$, da Constituição da República). O direito à saúde, na sua mais ampla acepção de sadia qualidade de vida, compreende a tutela integral do trabalhador na sua condição humana, cuja violação caracteriza dano extrapatrimonial.

Ainda nesse contexto, com relação à previdência social, o art. 201, § 11, da Constituição da República diz que os ganhos habituais do empregado, a qualquer título, devem ser incorporados ao salário para efeito de contribuições previdenciárias e consequente repercussão na cobertura dos eventos de doença, invalidez, morte e idade avançada; proteção à maternidade, especialmente à gestante; proteção ao trabalhador em situação de desemprego involuntário; salário-família e auxílio-reclusão para os dependentes dos segurados de baixa renda; e pensão por morte do segurado, homem ou mulher, ao cônjuge ou companheiro e dependentes (art. 201, caput e I a V, da Constituição da República).

Os direitos de personalidade, plasmados no art. $5^{\circ}, \mathrm{V}$ e X, da Constituição da República, consubstanciam "verdadeira cláusula geral de proteção à personalidade", qual seja, o art. $1^{\circ}$, III, da Constituição da República, "que assegura a dignidade da pessoa humana 
como fundamento de todo Estado Democrático de Direito. Assim, toda a ordem jurídica deve ser interpretada à luz do princípio da máxima efetividade dos direitos de personalidade". ${ }^{32}$.

Desta forma, como visto, a razão de ser do Direito do Trabalho é a proteção da parte vulnerável, o que demanda um procedimento especial. Nesse sentido, a Consolidação das Leis do Trabalho, decretada por Getúlio Vargas em $1^{\circ}$ de maio de 1943, consoante Decreto-Lei 5.452, daquele ano, foi pioneira "na demonstração de preocupação do legislador com os direitos coletivos, ainda que restrita ao âmbito do direito do trabalho, em oposição ao individualismo então predominante"; "sob o enfoque do acesso à justiça, assinale-se que a Consolidação das Leis do Trabalho acolheu um procedimento mais simples e econômico, caracterizado por sua informalidade e celeridade". ${ }^{33}$

\title{
5. A garantia constitucional da indenizabilidade irrestrita em contraponto com a tarifação do dano extrapatrimonial
}

Como vimos, a Constituição da República, após relatar quais são seus princípios (art. $1^{\circ}$ ) e objetivos fundamentais (art. $3^{\circ}$ ), inclusive no âmbito internacional (art. $4^{\circ}$ ), inaugura, logo em seguida, o seu Título II, que consagra e consolida direitos e garantias fundamentais expressos (mormente os arts. $5^{\circ}$ a 12 ).

Dentro do art. $5^{\circ}$, que trata dos direitos e deveres individuais e coletivos, espécie do gênero direitos e garantias fundamentais, eminentemente humanos, inerentes à tutela da dignidade da pessoa humana, ${ }^{34}$ temos assentados os incisos V e X, que estabelecem: ${ }^{35}$

\begin{abstract}
Art. $5^{\circ}($...) $\mathrm{V}$ - é assegurado o direito de resposta, proporcional ao agravo, além da indenização por dano material, moral ou à imagem; (...) X - são invioláveis a intimidade, a vida privada, a honra e a imagem das pessoas, assegurado o direito a indenização pelo dano material ou moral decorrente de sua violação;
\end{abstract}

De início, registre-se que mencionados dispositivos são pétreos e de aplicação imediata (arts. $5^{\circ}, \S 1^{\circ}$, e $60, \S 4^{\circ}, I V$, da Constituição da República).

Quando falamos em direitos de natureza "pétrea" (art. 60, § 4 , da Constituição da República), reconhecemos não apenas que são infensos à supressão posterior, mas também que não são passíveis de diminuição ou retaliação do seu alcance. Segundo já decidiu o

\footnotetext{
32 DALleGRAVE NETO, José Affonso. Responsabilidade civil no direito do trabalho. 6. ed. São Paulo: LTr, 2017, p. 161.

${ }^{33}$ PAROSKI, Mauro Vasni. Direitos fundamentais e acesso à justiça na Constituição. São Paulo: LTr, 2008, p. 187.

${ }^{34}$ BALERA, Wagner. A seguridade social na Constituição de 1988. São Paulo: RT, 1989, p. 17.

${ }^{35}$ Observar a palavra em destaque ("proporcional"), cujo significado e interpretação - hermenêutica adequada serão abordados mais à frente.
} 
Supremo Tribunal Federal, a Constituição da República emprestou à reparação decorrente do dano moral tratamento especial, ao proceder à previsão expressa nos incisos $\mathrm{V}$ e $\mathrm{X}$ do $\operatorname{art} .5^{\circ}-$ um artigo topograficamente privilegiado e de altíssima carga axiológico-teleológica -, desejando que a indenização decorrente desse dano fosse a mais ampla, não sendo possível sujeitá-la aos limites estreitos de nenhuma lei infraconstitucional. ${ }^{36}$

Em outra assentada, o Supremo Tribunal Federal utilizou-se de uma expressão singular e representativa da grandeza do dispositivo constitucional: indenizabilidade irrestrita; com efeito, segundo a Suprema Corte, toda a limitação indenizatória (ao valor) do dano, de forma prévia e abstrata pela legislação infraconstitucional, é incompatível com o alcance da indenizabilidade irrestrita assegurada pela atual Constituição da República. ${ }^{37}$

Segundo o Supremo Tribunal Federal, a indenização deve ser objeto de juízo de equidade ${ }^{38}$ Mauricio Godinho Delgado e Gabriela Neves Delgado ${ }^{39}$ bem acrescentam que o art. $5^{\circ}, \mathrm{V}$, da Constituição da República menciona enfaticamente a noção de proporcionalidade. Nesse contexto, a interpretação lógico-racional, sistemática e teleológica desses dispositivos legais rejeita a absolutização do tarifamento", com a prevalência da "noção jurídica advinda do princípio da proporcionalidade-razoabilidade". Nesse ponto, o art. $5^{\circ}, \mathrm{V}$, da Constituição da República "afasta o critério de tarifação da indenização por dano moral". ${ }^{40}$

Em um processo objetivo, pertinente ao controle concentrado de constitucionalidade uma Arguição de Descumprimento de Preceito Fundamental ${ }^{41}$, o Supremo Tribunal Federal reafirmou que, no tocante à indenização por dano moral, "de longa data" a jurisprudência da Suprema Corte consolidou entendimento no sentido de afastar a possibilidade do estabelecimento de qualquer tarifação, "confirmando, nesse aspecto, a Súmula 281 do Superior Tribunal de Justiça"42.

\footnotetext{
36 Recurso Extraordinário 396386/SP, Relator: Ministro Carlos Velloso, Julgamento: 29/06/2004, Órgão Julgador: Segunda Turma, Publicação: DJ 13/08/2004.

37 Recurso Extraordinário n. 447584/RJ, Relator: Ministro Cezar Peluso, Julgamento: 28/11/2006, Órgão Julgador: Segunda Turma, Publicação: DJ 16/03/2007.

38 Recurso Extraordinário n. 447584/RJ, Relator: Ministro Cezar Peluso, Julgamento: 28/11/2006, Órgão Julgador: Segunda Turma, Publicação: DJ 16/03/2007.

39 DELGADO, Mauricio Godinho; DELGADO, Gabriela Neves. A reforma trabalhista no Brasil: com os comentários à Lei n. 13.467/2017. 2. ed. rev., atual. e ampl. São Paulo: LTr, 2018, p. 148.

40 DELGADO, Mauricio Godinho; DELGADO, Gabriela Neves. A reforma trabalhista no Brasil: com os comentários à Lei n. 13.467/2017. 2. ed. rev., atual. e ampl. São Paulo: LTr, 2018, p. 148.

41 Arguição de Descumprimento de Preceito Fundamental n. 130/DF, Relator: Ministro Carlos Britto, Julgamento: 30/04/2009, Órgão Julgador: Tribunal Pleno, Publicação: DJe 6/11/2009.

${ }^{42}$ Súmula 281 do STJ: "A indenização por dano moral não está sujeita à tarifação prevista na Lei de Imprensa".
} 
Num dos julgados ${ }^{43}$ que consta nas razões de decidir da Súmula $281,{ }^{44}$ o Superior Tribunal de Justiça consignou o seguinte:

\begin{abstract}
Aliás, seria mesmo inconcebivel, sob pena de a lógica deixar de ser o caminho certo do raciocínio, que uma ofensa à honra feita pessoalmente por um indivíduo a outro, num ambiente restrito, pudesse, pelo menos em tese, sofrer indenização na exata extensão da reparabilidade plena do dano causado, enquanto que o dano decorrente de uma notícia maliciosa que a propagasse, de efeito destrutivo bem mais intenso, ficasse limitada apenas aos contornos da tarifação prevista na Lei de Imprensa. (destaques nossos)
\end{abstract}

O próprio Supremo Tribunal Federal, na Arguição de Descumprimento de Preceito Fundamental, ${ }^{45}$ trouxe o caminho adequado para a fixação do quantum a título de danos extrapatrimoniais: tendo em vista os princípios da equidade e da razoabilidade, além de outros critérios como o da gravidade e a extensão do dano; a reincidência do ofensor; a posição profissional e social do ofendido; e a condição financeira do ofendido e do ofensor, sempre submetidas ao crivo do sistema recursal - inclusive, não somente nas instâncias ordinárias, pois as instâncias extraordinárias se rogam legítimas para analisar tais valores se forem considerados ínfimos ou exacerbados, sem que isso signifique revisitar o conteúdo fáticoprobatório processual, em razão da possibilidade de violação - com valores aquém ou além do razoável - do art. 5, V e X, da Constituição da República ou do art. 944 do Código Civil, para o qual a indenização se mede pela extensão do dano.

Na VI Jornada de Direito Civil, organizada pelo Conselho da Justiça Federal, com a coordenação-geral do Ministro Ruy Rosado de Aguiar, do Superior Tribunal de Justiça, dentro da comissão de trabalho Responsabilidade Civil, coordenada pelo Ministro Paulo de Tarso Sanseverino, também do Superior Tribunal de Justiça, consagrou-se o Enunciado 550, ${ }^{46}$ segundo o qual "a quantificação da reparação por danos extrapatrimoniais não deve estar sujeita a tabelamento ou a valores fixos", sob a seguinte justificativa:

Cada caso é um caso”. Essa frase, comumente aplicada na medicina para explicar que o que está descrito nos livros pode diferir da aplicação prática, deve ser trazida para o âmbito jurídico, no tocante aos danos morais. Há três anos, o STJ buscou parâmetros para uniformizar os valores dos danos morais com base em jurisprudências e fixou alguns valores, por exemplo, para os casos de morte de filho no parto (250 salários) e paraplegia (600 salários). Da análise desse fato, devemos lembrar que a linha entre a indenização ínfima e o enriquecimento sem causa é muito tênue; entretanto, a análise do caso concreto deve ser sempre priorizada.

\footnotetext{
${ }^{43}$ Recurso Extraordinário n. 63520/RJ, Relator: Ministro Barros Monteiro, Redator para o Acórdão: Ministro Ruy Rosado de Aguiar, Órgão Julgador: Quarta Turma, Data do Julgamento: 18/6/1998, Data da Publicação: DJ 19/10/1998.

$44 \quad$ Disponível em: <https://ww2.stj.jus.br/docs_internet/revista/eletronica/stj-revista-sumulas2011_21_capSumula281.pdf>. Acesso em: 31 jul. 2018.

45 Arguição de Descumprimento de Preceito Fundamental n. 130/DF, Relator: Ministro Carlos Britto, Julgamento: 30/04/2009, Órgão Julgador: Tribunal Pleno, Publicação: DJe 6/11/2009.

${ }^{46}$ Disponível em: <http://www.cjf.jus.br/enunciados/enunciado/621>. Acesso em: 31 jul. 2018.
} 
Caso contrário, corremos o risco de voltar ao tempo da Lei das XII Tábuas, em que um osso quebrado tinha um valor e a violência moral, outro. Quando um julgador posiciona-se acerca de um dano moral, deve atentar para alguns pontos, entre os quais a gravidade do fato, a extensão do dano, a posição social e profissional do ofendido, a condição financeira do agressor e do agredido, baseando-se nos princípios da razoabilidade, equidade e proporcionalidade, além da teoria do desestímulo. Dessa forma, a chance de resultados finais serem idênticos é praticamente nula. O juiz não pode eximir-se do seu dever de analisar, calcular e arbitrar a indenização dentro daquilo que é pretendido entre as partes. Assim, considerando o que temos exposto, conclui-se que não deve existir limitação prévia de valores, sob o risco de fomentarmos a diabólica indústria do dano moral. (destaques nossos)

A reparação, em síntese, volta-se ao prejuízo injustamente perpetrado à vítima pelo ofensor - mesmo tratamento dado no direito francês, como preceituam Geneviève Viney e Patrice Jourdain: ${ }^{47}$ "Il a déjà été souligné que le droit de la responsabilité civile en France, comme d'ailleurs dans la plupart des pays étrangers, est orienté principalement vers la réparation des dommages qui constitue son objectif prioritaire".

Porém, quanto à possibilidade prévia e abstrata de tarifação do dano, pela legislação, há muito, no direito francês, ela é absolutamente rechaçada, conforme sólida doutrina:

Pour apprécier l'étendue du préjudice patrimonial, les juges doivent rechercher in concreto tous les éléments qui permettent d'apprécier, de la façon la plus exacte possible, la perte économique prévisible du handicap sur la capacité de travail de la victime, le régleur, qu'il soit juge ou assureur, ne peut se satisfaire d'une évaluation médico-légale formalisée par un taux d'incapacité fonctionnelle, mais doit apprécier, eu égard à la situation professionnelle de la vitime, quelle peut être l'impact économique réel de son déficit séquellaire. ${ }^{48}$

De outra banda, o art. $5^{\circ}, \S 1^{\circ}$, da Constituição da República "autoriza que os operadores do direito, mesmo à falta de comando legislativo, venham a concretizar os direitos fundamentais pela via interpretativa", ${ }^{49}$ mormente diante da inafastabilidade da jurisdição e do poder/dever inserto na atuação judiciária de entregar a ordem jurídica justa (art. $5^{\circ}, \mathrm{XXXV}$, da Constituição da República). A vinculação do Poder Judiciário "gera o poder-dever de recusar aplicação a preceitos que não respeitem direitos fundamentais" ${ }^{50}$ O Poder Judiciário pode, então, "dar aplicação aos direitos fundamentais mesmo contra a lei". ${ }^{51}$

\footnotetext{
${ }^{47}$ VINEY, Geneviève; JORDAIN, Patrice. Traité de droit civil: les effets de la responsabilité. 3. ed. Paris: LGDJ, 2010, p. 154.

${ }^{48}$ VINEY, Geneviève; JORDAIN, Patrice. Traité de droit civil: les effets de la responsabilité. 3. ed. Paris: LGDJ, 2010, p. 278.

${ }^{49}$ MENDES, Gilmar Ferreira; BRANCO, Paulo Gustavo Gonet. Curso de Direito Constitucional. 12. ed. rev. e atual. São Paulo: Saraiva, 2017, p. 152.

${ }^{50}$ MENDES, Gilmar Ferreira; BRANCO, Paulo Gustavo Gonet. Curso de Direito Constitucional. 12. ed. rev. e atual. São Paulo: Saraiva, 2017, p. 151.

${ }^{51}$ MENDES, Gilmar Ferreira; BRANCO, Paulo Gustavo Gonet. Curso de Direito Constitucional. 12. ed. rev. e atual. São Paulo: Saraiva, 2017, p. 152.
} 
Relembre-se que, dada a centralidade dos direitos fundamentais na Constituição da República e, ainda, segundo o próprio Pacto Internacional sobre Direitos Econômicos, Sociais e Culturais, de posição hierárquico-normativa de supralegalidade, o Brasil deve se comprometer a adotar medidas legislativas - mormente com o fomento da legislação infraconstitucional -, que visem a assegurar por todos os meios apropriados o pleno exercício desses direitos fundamentais, de forma progressiva e permanente.

A tutela da dignidade da pessoa humana, por corolário lógico, perpassa a máxima efetividade e concretização dos direitos à intimidade, à vida privada, à honra e à imagem das pessoas e todos os outros direitos conexos a esse arcabouço axiológico - dado o rol meramente exemplificativo trazido na Lei Maior -, além da permanente e progressiva higidez e amplitude quanto à tutela desses direitos e a garantia de indenização por dano material, moral ou à imagem, quando se fizerem necessários ao resguardo e promoção da dignidade da pessoa humana e sua elevada carga valorativa.

Nesse contexto, a Lei 13.467/2017, intitulada de "Reforma Trabalhista", sob a justificativa de "adequar a legislação às novas relações de trabalho", conforme consta expressamente na sua ementa, ${ }^{52}$ incluiu o Título II-A à Consolidação das Leis do Trabalho, nomeado "Do Dano Extrapatrimonial”, com destaque nosso para o art. 223-G, cujos $\S \S 1^{\circ}$ e $2^{\circ}$ dizem o seguinte:

Art. 223-G. (...) $§ 1^{\circ}$ Se julgar procedente o pedido, o juízo fixará a indenização a ser paga, a cada um dos ofendidos, em um dos seguintes parâmetros, vedada a acumulação: I - ofensa de natureza leve, até três vezes o último salário contratual do ofendido; II - ofensa de natureza média, até cinco vezes o último salário contratual do ofendido; III - ofensa de natureza grave, até vinte vezes o último salário contratual do ofendido; IV - ofensa de natureza gravíssima, até cinquenta vezes o último salário contratual do ofendido. $\S 2^{\circ} \mathrm{Se}$ o ofendido for pessoa jurídica, a indenização será fixada com observância dos mesmos parâmetros estabelecidos no § $1^{\circ}$ deste artigo, mas em relação ao salário contratual do ofensor.

A Medida Provisória 808/2017, posteriormente, com a pretensão de "aprimoramento de dispositivos pontuais", segundo se fez constar na Exposição de Motivos ${ }^{53}$ modificou o critério, do salário contratual do ofendido para o limite máximo dos benefícios do Regime Geral de Previdência Social.

\footnotetext{
52 A Lei Complementar 95/1998, que dispõe sobre a elaboração, a redação, a alteração e a consolidação das leis, conforme determina o parágrafo único do art. 59 da Constituição da República, em seu art. $5^{\circ}$, diz que "a ementa será grafada por meio de caracteres que a realcem e explicitará, de modo conciso e sob a forma de título, o objeto da lei”.

53 Disponível em: <http://www.planalto.gov.br/ccivil_03/_ato2015-2018/2017/Exm/Exm-MP-808-17.pdf>. Acesso em: 31 jul. 2018.
} 
$\mathrm{Na}$ referida Exposição de Motivos, para essa modificação, em especial, assim constaram as justificativas:

10.3 No que se refere ao dano extrapatrimonial, a fixação de limites para as indenizações por danos morais com base em critérios objetivos tem por objetivo evitar que haja decisões judiciais díspares para situações semelhantes, ao mesmo tempo em que busca estabelecer uma gradação de valores a partir da classificação da ofensa por sua gravidade. Para tanto, são realizadas alterações nos $\S \S 1^{\circ}$ e $3^{\circ}$, além de inclusões dos $\S \S 4^{\circ}$ e $5^{\circ}$ ao art. 223-G do Decreto-Lei $n^{\circ} 5.452$, de 1943, apresentando dosimetria para a fixação da reparação a ser paga aos ofendidos em casos de dano moral ou existencial, estabelecendo o limite máximo dos benefícios do Regime Geral de Previdência Social - RGPS como parâmetro de reparação. São apresentados limites máximos a depender do grau de gravidade da ofensa variando de ofensa de natureza leve a gravíssima. Os cenários apresentados visam possibilitar que o juízo arbitre a reparação que melhor se adequar ao caso concreto, além de reservar a possibilidade de o Juízo dobrar o valor da indenização nos casos em que haja reincidência de qualquer das partes.

Porém, como sabemos, a Medida Provisória 808/2017 perdeu sua eficácia, desde a edição, porque não foi convertida em lei no prazo de que tratam os $\S \S 3^{\circ}$ e $7^{\circ}$ do art. 62 da Constituição da República. Contudo, as relações jurídicas ocorridas durante sua vigência podem acabar sendo por ela reguladas já que ainda não sobreveio, sequer, o decreto legislativo para disciplinar essa matéria (art. 62, §§ $3^{\circ}$ e 11, da Constituição da República).

Assim, permanece, como critério-base, o salário do trabalhador.

A norma sancionada (Lei 13.467/2017), ao modificar a Consolidação das Leis do Trabalho para introduzir uma tarifação prévia e abstrata, por meio de uma norma infraconstitucional, incorre, em nosso sentir, em grave vício material de inconstitucionalidade, por afrontar direta e literalmente a inteligência do art. $5^{\circ}, \mathrm{V}$ e $\mathrm{X}$, da Constituição da República; incorre em antinomia com a norma-regra contida no art. 944 do Código Civil; além de grave vício de inconvencionalidade, por afrontar um tratado internacional de direitos humanos, que ostenta posição hierárquico-normativa de supralegalidade, qual seja, o Pacto Internacional sobre Direitos Econômicos, Sociais e Culturais, devendo, nesse sentido, segundo iterativa, atual e notória jurisprudência do Supremo Tribunal Federal, sofrer eficácia paralisante.

Afronta ainda direta e literalmente a inteligência do art. $5^{\circ}, \mathrm{V}$ e X, da Constituição da República, conforme amplamente visto neste estudo, por não se adequar ao que o Supremo Tribunal Federal concebeu chamar de "indenizabilidade irrestrita", ao impor limites pecuniários ao valor da indenização. Como vimos, toda a limitação indenizatória (ao valor) do dano, de forma prévia e abstrata pela legislação infraconstitucional, é incompatível com o alcance da indenizabilidade irrestrita assegurada pela atual Constituição da República. 
Ademais, o art. 5, $\mathrm{V}$, da Constituição da República já define, expressamente, um critério de fixação do quantum, qual seja, uma interpretação lógico-racional, sistemática e teleológica que rejeita a absolutização do tarifamento e aplica o princípio da proporcionalidade-razoabilidade.

Nesse sentido, desde 1942, a Lei de Introdução às normas do Direito Brasileiro prevê, por seu art. $5^{\circ}$, que na aplicação da lei o juiz atenderá aos fins sociais a que ela se dirige e às exigências do bem comum. O novo Código de Processo Civil, de 2015, passou a prever, por seu art. $8^{\circ}$, que ao aplicar o ordenamento jurídico o juiz atenderá aos fins sociais e às exigências do bem comum, resguardando e promovendo a dignidade da pessoa humana - a tutela da dignidade da pessoa humana tratada ao longo deste estudo - e observando a proporcionalidade, a razoabilidade, a legalidade, a publicidade e a eficiência.

A Lei 13.467/2017 desrespeita o entendimento, manifestado em diversos processos subjetivos e objetivos - pelo Supremo Tribunal Federal, de impossibilidade do estabelecimento de qualquer tarifação, pois é inconcebível que uma ofensa à honra feita pessoalmente por um indivíduo a outro, num ambiente restrito, possa, sequer em tese, sofrer indenização na exata extensão da reparabilidade plena do dano causado.

Os parâmetros para a fixação do quantum já foram reiteradamente expostos não só pelo Supremo Tribunal Federal como igualmente pelo Superior Tribunal de Justiça e pelo Tribunal Superior do Trabalho, e todos esses tribunais superiores, a quem a Constituição da República encarrega a uniformização da Constituição e da legislação infraconstitucional, conforme o caso, são unânimes em definir a proporcionalidade e a razoabilidade como bases a serem seguidas - e nunca um tabelamento prévio.

A centralidade constitucional da dignidade da pessoa humana e dos direitos fundamentais vincula o Poder Judiciário a amplamente rechaçar preceitos que não respeitem direitos fundamentais, o que é o caso, em nossa percepção.

De outra banda, pelos mesmos motivos, a novel legislação é antinômica ao se confrontar seu conteúdo com o art. 944 do Código Civil, pois, segundo o comando civil, a indenização se mede pela extensão do dano, o que não ocorrerá quando o julgador estiver adstrito e limitado a valores prévios, independentemente do caso concreto analisado. Nesse sentido, ao que parece, a Lei 13.467/2017 incide em manifesta violação ao princípio da isonomia, uma vez que discrimina de forma negativa uma categoria de pessoas, os 
trabalhadores, que se encontram em condições de vulnerabilidade, a priori, mais graves que em relações privadas comuns.

De outra banda, viola o Pacto Internacional sobre Direitos Econômicos, Sociais e Culturais, na medida em que traz legislação em franco retrocesso social, com limitação à própria fundamentalidade da Constituição da República e da indenizabilidade irrestrita salvaguardada no art. 5\%, V e X, da Lei Maior. Com a aprovação da "Reforma Trabalhista", mormente no campo dos direitos da personalidade e de indenização por dano extrapatrimonial, o Estado brasileiro demonstrou seu descompromisso com medidas aptas a assegurar o pleno exercício de direitos fundamentais e sociais.

E não é só.

A discriminação negativa inferioriza a pessoa humana do trabalhador, tanto de forma externa quando se compara com as demais relações jurídicas, bem como de forma interna, ao adotar o valor do salário como patamar para dosar o dano extrapatrimonial, discriminando a pessoa humana do trabalhador segundo o seu respectivo patamar salarial. Como bem coloca Sebastião Geraldo de Oliveira ${ }^{54}$ a "Reforma Trabalhista" fere a Constituição da República "ao estabelecer parâmetros de reparação de danos francamente discriminatórios, porque fixados com valores variáveis de acordo com o padrão salarial da vítima”. Nesse sentido, a norma é materialmente inconstitucional, por afrontar o art. $5^{\circ}$, caput, da Constituição da República, sendo visivelmente anti-isonômica.

Nada justifica a diferenciação. Imaginemos um engenheiro de obras e um pedreiro que morrem em um acidente do trabalho, em idêntica circunstância e no mesmo evento fatal. O que diferencia a vida de um e de outro? É inaceitável e repudiável que, para isto, a legislação dê tratamento diverso apenas e tão somente pelo aspecto financeiro e pelo salário contratual do ofendido. Essa diferenciação, segundo entendemos, reconhece a nossa desigualdade ilegítima - perante a lei, em ampla afronta ao art. $5^{\circ}$, caput, da Constituição da República; ao mesmo tempo, é violadora de objetivos fundamentais da República Federativa do Brasil, como a promoção do bem de todos, sem qualquer forma de discriminação, e a erradicação da pobreza, da marginalização e das desigualdades (art. 3º, III e IV, da Constituição da República), além de criar patamares diferenciados de cidadania (art. $1^{\circ}$, II, da Constituição da República) e de dignidade (art. $1^{\circ}$, III, da Constituição da República).

\footnotetext{
${ }^{54}$ OLIVEIRA, Sebastião Geraldo de. O dano extrapatrimonial trabalhista após a Lei n. 13.467/2017, modificada pela MP n. 808, de 14 novembro de 2017. Revista do Tribunal Regional do Trabalho da $3^{a}$ Região. Belo Horizonte, edição especial, p. 333-368, nov. 2017, p. 359.
} 
Assim, o tratamento legal diferenciado é ilícito, baseado em discriminações juridicamente intoleráveis e socialmente inaceitáveis, motivado por distinções odiosas, por preconceito e tomadas gratuitamente. Como já registramos outrora, muito bem colocou Boaventura de Sousa Santos e João Arriscado Nunes: ${ }^{55}$ temos o direito a ser iguais quando a nossa diferença nos inferioriza, daí a necessidade de uma diferença que não produza, alimente ou que reproduza desigualdades - o que é o caso da Lei 13.467/2017.

Por fim, a "Reforma Trabalhista" também desconsidera a importância do elemento trabalho - e sua necessidade de valorização, proteção e salvaguarda -, em franco descompasso com a Declaração Universal dos Direitos Humanos e a constituição da Organização Internacional do Trabalho e outros importantes tratados internacionais de direitos humanos, por fazer equivaler o trabalho a uma mercadoria.

Também afronta a Constituição da República, que institui Estado Democrático de Direito que tem como fundamentos, entre outros, a cidadania e a dignidade da pessoa humana (art. $1^{\circ}$, II e III, da Constituição da República), na medida em que coloca o trabalhador mormente o mais humilde, o mais necessitado - como um cidadão inferior, de segunda classe, além de desconsiderar que a própria ordem econômica é fundada na valorização do trabalho humano, tendo por fim assegurar a todos existência digna, conforme os ditames da justiça social (art. 170 da Constituição da República), e que a ordem social tem como base o primado do trabalho, e como objetivo o bem-estar e a justiça sociais (art. 193 da Constituição da República), pela criação de uma legislação trabalhista que conduza a uma menor proteção que aquela conferida pelo direito comum.

\section{Conclusão}

Como vimos ao longo desse estudo, embora tardia, a Constituição da República Federativa do Brasil, de 1988, foi revolucionária, ao reconhecer, pela topografia e por seu conteúdo material, expressamente, a centralidade dos direitos fundamentais dentro do Estado Democrático de Direito, que impõe uma cidadania digna.

Nesse sentido, é cara, ao Estado brasileiro, a amplíssima tutela às situações existenciais da pessoa humana, seja pela ameaça ou pela concretização do dano, cuja

55 SANTOS, Boaventura de Sousa; NUNES, João Arriscado. Introdução: para ampliar o cânone do reconhecimento, da diferença e da igualdade. In: SANTOS, Boaventura de Sousa (org.). Reconhecer para libertar: os caminhos do cosmopolitismo multicultural. Rio de Janeiro: Civilização Brasileira, 2003, p. 25-68, p. 56. 
tarifação, de forma prévia e abstrata pela legislação infraconstitucional, como estabeleceu a Reforma Trabalhista, é incompatível com a indenizabilidade irrestrita forjada no art. $5^{\circ}, \mathrm{V}$ e X, da Constituição da República, que estabelece, ainda, um critério prévio, dentro de uma interpretação lógico-racional, sistemática e teleológica, de absoluta rejeição à tarifação e de prevalência da noção jurídica advinda do princípio da proporcionalidade-razoabilidade.

Ainda, a importância do elemento trabalho - e sua necessidade de valorização, proteção e salvaguarda -, o qual por não ser mercadoria, impõe ao Estado brasileiro que garanta em sua legislação, com o máximo de esforço e comprometimento, uma legislação superior ao que propõe o direito comum, que seja adequada ao paradigma da essencialidade que permeia as relações laborais e que possa elevar a cidadania do trabalhador a patamar constitucional, com a promoção do bem de todos, sem qualquer forma de discriminação, a erradicação da pobreza, da marginalização e das desigualdades, inclusive diante do princípio constitucional da isonomia, que rechaça um tratamento legal diferenciado ilícito, baseado em discriminações juridicamente intoleráveis e socialmente inaceitáveis, motivado por distinções odiosas e por preconceito.

Porém, em que pese a Reforma Trabalhista, como bem colocara Tepedino ${ }^{56}$ :

De nada adiantaria aguardar a intervenção reformista do legislador, sendo mais útil, ao revés, e urgente, procurar soluções interpretativas que ampliem a proteção da pessoa humana, atribuindo-se a máxima efetividade social aos princípios constitucionais e aos tratados internacionais que ampliam o leque de garantias fundamentais da pessoa humana. (destaques nossos)

Dentro do Estado Democrático de Direito, impõe-se ao juiz que, ao aplicar o ordenamento jurídico, considere o atendimento aos fins sociais e às exigências do bem comum, no sentido resguardar e promover a dignidade da pessoa humana em observância aos tratados internacionais de direitos humanos ratificados pelo Brasil, de posição hierárquiconormativa de supralegalidade.

A Constituição da República impõe ao magistrado o poder/dever de concretizar os direitos fundamentais pela via interpretativa, devendo recusar aplicação a preceitos que não respeitem direitos fundamentais. Nesses termos, o art. 223-G, $\S \S 1^{\circ}$ e $2^{\circ}$, da CLT é materialmente inconstitucional e inconvencional, devendo-se-lhe recusar aplicação.

56 TEPEDINO, Gustavo. Cidadania e direitos da personalidade. Cadernos da Escola de Direito e Relações Internacionais das Faculdades do Brasil, Paraná, v. 1, n. 3, p. 15-31, jan./jun. 2003, p. 46. 


\section{Referências}

ALEXY, Robert. Teoria dos direitos fundamentais. São Paulo: Malheiros, 2008.

BALERA, Wagner. A seguridade social na Constituição de 1988. São Paulo: RT, 1989.

BONNA, Aline Paula. A vedação do retrocesso social como limite à flexibilização das normas trabalhistas brasileiras. Revista do Tribunal Regional do Trabalho da $3^{a}$ Região, Belo Horizonte, v. 47, n. 77, p. 51-66, jan./jun. 2008.

CANARIS, Claus-Wilhelm. Pensamento sistemático e conceito de sistema na ciência do direito. Lisboa: Fundação Calouste Gulbenkian, 2008.

DALLEGRAVE NETO, José Affonso. Responsabilidade civil no direito do trabalho. 6. ed. São Paulo: LTr, 2017.

DELGADO, Mauricio Godinho; DELGADO, Gabriela Neves. A reforma trabalhista no Brasil: com os comentários à Lei n. 13.467/2017. 2. ed. rev., atual. e ampl. São Paulo: LTr, 2018.

DINIZ, Maria Helena. Dicionário jurídico. 2. ed. rev., atual. e aum. São Paulo: Saraiva, 2005. Vol. 1, A-C.

FARIAS, Cristiano Chaves de; ROSENVALD, Nelson; BRAGA NETTO, Felipe Peixoto. Curso de Direito Civil: responsabilidade civil. 2. ed. rev., atual. e ampl. São Paulo: Atlas, 2015. vol. 3.

HOUAISS, Antônio; VILLAR, Mauro de Salles; FRANCO, Francisco Manoel de Mello. Dicionário Houaiss da língua portuguesa. Rio de Janeiro: Objetiva, 2009.

JELLINEK, Georg. A declaração dos direitos do homem e do cidadão: contribuição para a história do direito constitucional moderno [trad. Emerson Garcia]. São Paulo: Atlas, 2015.

LEAL, Pastora do Socorro Teixeira. "Dialogo das fontes" e coerência na concretização de direitos fundamentais. In: VELOSO, Zeno; OLIVEIRA, Frederico Antônio Lima de; BACELAR, Jeferson Antônio Fernandes (orgs.). Ciência e interpretação do Direito: homenagem a Daniel Coelho de Souza. Rio de Janeiro: Lumen Juris, 2016.

LORENTZ, Lutiana Nacur. A norma da igualdade e o trabalho das pessoas portadoras de deficiência. 2. ed. São Paulo: LTr, 2016.

MENDES, Gilmar Ferreira; BRANCO, Paulo Gustavo Gonet. Curso de Direito Constitucional. 12. ed. rev. e atual. São Paulo: Saraiva, 2017.

NEGREIROS, Teresa. Teoria do contrato: novos paradigmas. 2. ed. Rio de Janeiro: Renovar, 2006. 
OLIVEIRA, Sebastião Geraldo de. O dano extrapatrimonial trabalhista após a Lei n. 13.467/2017, modificada pela MP n. 808, de 14 novembro de 2017. Revista do Tribunal Regional do Trabalho da $3^{a}$ Região. Belo Horizonte, edição especial, p. 333-368, nov. 2017.

PAROSKI, Mauro Vasni. Direitos fundamentais e acesso à justiça na Constituição. São Paulo: LTr, 2008.

SANTOS, Boaventura de Sousa; NUNES, João Arriscado. Introdução: para ampliar o cânone do reconhecimento, da diferença e da igualdade. In: SANTOS, Boaventura de Sousa (org.). Reconhecer para libertar: os caminhos do cosmopolitismo multicultural. Rio de Janeiro: Civilização Brasileira, 2003. p. 25-68.

SARLET, Ingo Wolfgang. In: CANOTILHO, José Joaquim Gomes et al. Comentários à Constituição do Brasil. Saraiva/Almedina: São Paulo/Portugal, 2013.

STRECK, Lenio Luiz; MORAIS, Jose Luis Bolzan de. In: CANOTILHO, José Joaquim Gomes et al. Comentários à Constituição do Brasil. Saraiva/Almedina: São Paulo/Portugal, 2013.

TEPEDINO, Gustavo. Cidadania e direitos da personalidade. Cadernos da Escola de Direito e Relações Internacionais das Faculdades do Brasil, Paraná, v. 1, n. 3, p. 15-31, jan./jun. 2003.

. Temas de Direito Civil. Rio de Janeiro: Renovar, 2009. t. III.

VINEY, Geneviève; JORDAIN, Patrice. Traité de droit civil: les effets de la responsabilité. 3. ed. Paris: LGDJ, 2010.

WEISS, Raquel. Max Weber e o problema dos valores: as justificativas para a neutralidade axiológica. Revista de Sociologia e Política, Curitiba, v. 22, n. 49, p. 113-137, mar. 2014.

ZWICKER, Igor de Oliveira. Súmulas, orientações jurisprudenciais e precedentes normativos do TST. São Paulo: LTr, 2015.

A dupla incompatibilidade vertical material do artigo 477-A da Consolidação das Leis do Trabalho. Jornal do $58^{\circ}$ Congresso Brasileiro de Direito do Trabalho. São Paulo, LTr, v. 58, p. 61-63, jun. 2018.

Como citar: LEAL, Pastora do Socorro Teixeira; ZWICKER, Igor de Oliveira. A incompatibilidade da tarifação da indenização por dano extrapatrimonial trabalhista à luz dos direitos humanos e dos direitos fundamentais. Revista IBERC, Minas Gerais, v. 1, n. 1, p. 0126, nov.-fev./2019. 